\title{
IDENTIFIKASI KONDISI DAN UPAYA PENGUATAN PENGAWASAN DALAM \\ RANGKA REFORMASI BIROKRSI DI KABUPATEN PEKALONGAN
}

\author{
Herbasuki $^{1}$
}

\begin{abstract}
Supervision is one of the areas of bureaucarcy reform that is expected to increase in clean governance and free of corruption, collusion and nepotism (KKN). The purpose of the study was to identify the internal oversight authority, issues and efforts to strengthen the government which's done by Pekalongan Regency. The study was conducted with a qualitative descriptive approach.

Supervisory authority pursue by the rules of Pekalongan Regency No. 56 of 2013 which includes monitoring the implementation of government affairs at the district level, village government affairs, internal control implementation of the tasks and functions performed by the Inspectorate.

The problems encountered by the activities of the budgeted plan in the planning documents, the quantity and quality of auditors is still lacking, unfavorable employment policy, the lack of budget and unstandard of operational project.

Efforts must be made in order to strengthen the supervision such as commitment and exemplary leadership, gradual addition of auditor, the addition of operational funds and increase the quality of personnel SPIP (Internal Control System of the Government) in a planning manner in order to assist the inspectorate and prevent acts of maladministration and fraud (irregularities) in governance.
\end{abstract}

Keywords: supervision, bureaucracy reforms

\section{PENDAHULUAN}

Grand Design Reformasi Birokrasi 2010-2025 (PP No 81 tahun 2010) menjadi acuan bagi Kementerian/Lembaga (K/L) dan Pemerintah Daerah dalam melakukan reformasi birokrasi dalam rangka mewujudkan tata kelola pemerintahan yang baik. Reformasi birokrasi merupakan tugas yang harus dilakukan baik oleh pemerintah pusat maupun pemerintah daerah.

Grand Design birokrasi harus dituangkan dalam bentuk operasional berupa Road Map Reformasi Birokrasi/RMRB (Permenpan-RB No 20 tahun 2010) yang disusun dan dilakukan setiap 5 (lima) tahun sekali dan merupakan rencana rinci pelaksanaan reformasi birokrasi dari satu tahapan ke tahapan selanjutnya selama

\footnotetext{
${ }^{1}$ Staf Pengajar Program Studi S1 Administrasi Publik FISIP - Undip
} 
lima tahun dengan sasaran per tahun yang jelas. Sasaran tahun pertama akan menjadi dasar bagi sasaran tahun berikutnya, begitupun sasaran tahun-tahun berikutnya mengacu pada sasaran tahun sebelumnya.

Ruang lingkup RMRB mencakup 3 hal yaitu : 1) Penguatan Birokrasi Pemerintah, 2) Tingkat pelaksanaan dan 3) program. Pada tingkat program berorientasi hasil (outcomes oriented programs), baik pada tingkat makro, meso, maupun tingkat mikro. Program pada tingkat mikro meliputi :
a. Manajemen Perubahan
b. Penataan Peraturan Perundang-undangan
C. Penataan dan Penguatan Organisasi
d. Penataan Tatalaksana
e. Penataan Sistem Manajemen SDM Aparatur
f. Penguatan Pengawasan
g. Penguatan Akuntabilitas Kinerja
h. Peningkatan Kualitas Pelayanan Publik
i. Monitoring, Evaluasi dan Pelaporan

Penguatan Pengawasan merupakan salah satu program yang harus dijalankan dalam reformasi birokrasi. Program dan kegiatan penguatan pengawasan dalam kerangka reformasi birokrasi ditujukan untuk meningkatkan penyelenggaraan pemerintahan yang bersih dan bebas Korupsi, Kolusi, Nepotisme. Program penguatan pengawasan terdiri dari dua kegiatan yaitu : 1) penerapan Sistem Pengendalian Intern Pemerintah (SPIP). SPIP adalah Sistem Pengendalian Intern (SPI) yang diselenggarakan secara menyeluruh di lingkungan pemerintah pusat dan pemerintah daerah (PP 60/2008, Bab I, Pasal 1 Butir 2 dan 2) peningkatan peran Aparat Pengawasan Intern Pemerintah (APIP) sebagai quality assurance dan consulting.

Program ini bertujuan untuk meningkatkan penyelenggaraan pemerintahan yang bersih dan bebas KKN pada masing-masing Kementerian/Lembaga dan Pemerintah Daerah. Target yang ingin dicapai melalui program ini adalah: 
a. meningkatnya kepatuhan terhadap pengelolaan keuangan negara oleh masing-masing K/L dan Pemda;

b. meningkatnya efektivitas pengelolaan keuangan negara pada masingmasing K/L dan Pemda;

c. meningkatnya status opini BPK terhadap pengelolaan keuangan negara pada masing-masing K/L dan Pemda;

d. menurunnya tingkat penyalahgunaan wewenang pada masing-masing K/L dan Pemda.

Kriteria keberhasilan program dan kegiatan penguatan pengawasan dalam rangka reformasi birokrasi adalah sebagai berikut:

a. Pada penerapan Sistem Pengendalian Intern Pemerintah (SPIP) di instansi adalah jumlah dan jenis temuan berkurang; dan temuan yang ada ditindaklanjuti;

b. Pada Peningkatan Peran Aparat Pengawasan Intern Pemerintah (APIP) sebagai Quality Assurance dan Consulting adalah Laporan keuangan mendapatkan opini WTP (Wajar Tanpa Pengecualian) dari BPK di tahun yang akan datang.

Pengawasan bukan merupakan suatu tujuan, melainkan sarana untuk meningkatkan efisiensi dalam melaksanakan kegiatan. Didalamnya termasuk unsur pencegahan terhadap penyimpangan-penyimpangan yang mungkin terjadi. Kegiatan pengawasan tidak hanya dilakukan dalam tahap pelaksanaan, artinya aspek pengawasan telah masuk tatkala proyek-proyek pembangunan masih dalam tahap perencanaan.

Pelaksanaan pengawasan belum berlangsung optimal karena: 1) banyak dan tersebarnya objek pemeriksaan, 2) keterbatasan aparat yang memiliki kemampuan SDM yang handal di bidang pengawasan dan 3) belum berjalannya secara baik pengawasan melekat setiap tingkat pimpinan kepada bawahan. Pelaksanaan pembangunan yang tidak sesuai dengan rencana dapat disebabkan antara lain : 
a. Ada hambatan yang tidak diketahui atau diperhitungkan pada waktu perencanaan

b. Ada perkembangan keadaan, yang tidak dapat diantisipasi pada tahap perencanaan

c. Realisasi perkiraan yang berbeda dari perencanaan

d. Atau karena perencanaannya yang keliru (Ginanjar 1997).

Oleh karena itu perlu dilakukan suatu kajian pengawasan yang berfokus pada penguatan pengawasan, terutama pada kewenangan dan upaya-upaya penguatan yang dilakukan untuk mencapai sasaran yang telah dirumuskan dalam grand design reformasi birokrasi.

Tujuan Penelitian ini adalah Mengidentifikasi kondisi pengawasan internal yang dilakukan oleh pemerintah Kabupaten Pekalongan; Mengidentifikasi masalah-masalah yang ada dalam pengawasan internal; dan Mengidentifikasi upaya penguatan pengawasan internal yang dilakukan pemerintah Kabupaten Pekalongan

Sistem pengawasan memegang peranan penting untuk memastikan bahwa segala sesuatunya berjalan sesuai dengan visi, misi, tujuan serta target-target organisasi. Sistem pengawasan memiliki dua tujuan utama yaitu akuntabilitas dan proses belajar. Sisi akuntabilitas, sistem pengawasan akan memastikan bahwa dana pembangunan digunakan sesuai dengan etika dan aturan hukum dalam rangka memenuhi rasa keadilan. Pada sisi proses belajar, sistem pengawasan akan memberikan informasi tentang dampak program atau intervensi yang dilakukan, sehingga pengambil keputusan dapat belajar tentang bagaimana menciptakan program yang lebih efektif.

Pengawasan internal pemerintah kabupaten secara keseluruhan merupakan tanggung jawab bupati. Cakupan pengawasan yang menjadi kewenangan kabupaten diatur di dalam Peraturan Daerah tentang Kewenangan Kabupaten. Pengawasan tersebut dilaksanakan oleh suatu Badan atau Lembaga Pengawas Kabupaten yang saat ini disebut Inspektorat. Inspektorat adalah lembaga teknis 
dan berfungsi sebagai unsur penunjang pemerintah kabupaten di bidang pengawasan. Inspektorat Kabupaten dipimpin oleh seorang kepala yang merupakan pejabat eselon IIb, yang kedudukannya setingkat dengan asisten sekretaris daerah, Kepala Dinas dan pimpinan lembaga teknis lainnya (Kepala Badan dan Kepala Kantor). Kepala Inspektorat bertanggung jawab kepada Bupati melalui Sekretaris Daerah.

Pengawasan adalah suatu kegiatan untuk memperoleh kepastian apakah pelaksanaan kegiatan telah dilakukan sesuai dengan rencana. Kegiatan pengawasan pada dasarnya membandingkan kondisi yang ada dengan yang seharusnya terjadi. Secara umum pengawasan membantu manajemen dalam tiga hal : (1) meningkatkan kinerja organisasi, (2) memberikan opini atas kinerja organisasi dan (3) mengarahkan manajemen untuk melakukan koreksi atas masalah-masalah pencapaian kinerja yang ada (Subarsono, 2011).

Keberadaan pengawasan di lingkungan organisasi publik pada awalnya ditekankan pada rule based auditing. Orientasi audit ini ditekankan pada kejadian-kejadian masa lampau dengan perhatian utama pada terjadi tidaknya penyimpangan. Pada tahapan ini auditor berperan sebagai watchdog. Tahapan berikutnya pengawasan diperankan sebagai expert atau konsultan. Dalam peran sebagai konsultan, pengawasan mulai berorientasi pada identifikasi kelemahankelemahan operasional maupun manajerial yang pada akhirnya konsultan memberikan sejumlah usul perbaikan sebagaimana layaknya seorang expert atau konsultan. Pada tahapan terakhir pengawasan harus mampu memastikan bahwa usul-usul perbaikan yang diajukan dapat terlaksana atau dalam hal ini auditor harus mampu berperan sebagai katalisator atau quality assurer.

Pengawasan ditujukan untuk menciptakan pemerintahan yang efisien, efektif berorientasi pada pencapaian visi dan misi. Melalui pengawasan diharapkan dapat diperoleh masukan bagi pengambil kebijakan untuk : (1) meniadakan kesalahan, penyimpangan, pemborosan, hambatan, (2) mencegah terulangnya kesalahan, penyimpangan, pemborosan, hambatan tersebut dan (3) 
mendapatkan cara-cara yang lebih baik untuk mencapai tujuan dalam melaksanakan tugas pokok dan fungsi organisasi dan pencapaian visi dan misi organisasi (LAN, 2003)

\section{METODE}

Pendekatan yang dipilih adalah jenis penelitian deskriptif. Jenis penelitian ini berupaya untuk memberikan gambaran mengenai suatu fenomena tertentu secara terperinci, yang pada akhirnya akan bermuara pada pemahaman yang lebih jelas mengenai fenomena yang diteliti yakni untuk menghasilkan gambaran mengenai pengawasan. Menurut Dunn ( 2003) model penelitian deskriptif mempunyai tujuan untuk menjelaskan dan/atau memprediksikan sebab-sebab dan konsekwensi-konsekuensi pilihan-pilihan yang ada.

Sesuai dengan tujuan penelitian, maka jenis penelitian yang dilakukan adalah penelitian deskriptif, sehingga data yang diperoleh akan diuraikan serinci mungkin, dengan metode analisis kualitatif. Guna melihat validitas data maka dilakukan dengan pendekatan triangulasi yang berarti membandingkan dan mengecek balik derajat kepercayaan suatu informasi yang diperoleh (Moleong, 2001). Data yang diperoleh merupakan bahan yang akan diamati dan analisis. Kemudian berdasarkan data tersebut dilakukan interprestasi.

\section{HASIL PENELITIAN}

Pengawasan internal pemerintah kabupaten secara keseluruhan merupakan tanggung jawab Bupati. Pengawasan merupakan tugas badan pengawas yang disebut dengan Inspektorat. Sesuai dengan Peraturan Bupati Pekalongan No 56 tahun 2013 tentang Kebijakan Pengawasan Atas Penyelenggaraan Pemerintahan Daerah di Lingkungan Pemerintah Kabupaten Pekalongan, aparat pengawas intern pemerintah (APIP) pada inspektorat kabupaten melakukan :

a. Pengawasan terhadap pelaksanaan urusan pemerintahan di daerah kabupaten 
b. Pengawasan terhadap pembinaan atas penyelenggaraan pemerintahan desa

c. Pengawasan terhadap pelaksanaan urusan pemerintahan desa

d. Pengawasan intern atas penyelenggaraan tugas dan fungsi perangkat daerah termasuk akuntabilitas keuangan daerah, dalam rangka memperkuat dan menunjang efektivitas SPIP.

Dalam peraturan bupati tersebut ruang lingkup pengawasan meliputi :

a. Pengawasan terhadap penyelenggaraan pemerintahan daerah, yang meliputi:

- Administrasi umum pemerintahan, yang meliputi : Kebijakan; Kelembagaan; Pegawai; Keuangan; dan Barang Daerah

- Urusan pemerintahan

b. Pengawasan terhadap pelaksanaan pembinaan penyelenggaraan urusan pemerintahan desa

c. Pengawasan terhadap penyelenggaraan administrasi pemerintahan desa

d. Pengawasan terhadap penyelenggaraan SPIP di lingkungan pemerintah kabupaten

e. Penanganan pengaduan masyarakat sehubungan dengan kinerja inspektorat maupun pengaduan lain yang mengandung unsur pengawasan

f. Pengawasan dengan yang difokuskan pada materi atau obyek khusus (tujuan tertentu).

Jumlah auditor yang terbatas menyebabkan pekerjaan pemeriksaan yang dilakukan juga terbatas. Dalam satu tahun anggaran pemeriksaan reguler mencapai 144 SKPD, pemeriksaan kasus 20 an dan pemeriksaan khusus sekitar 15 dalam setiap tahun. Pimpinan SKPD sudah menandatangani pakta integritas baik dengan BPK dan BPKP, sehingga diharapkan fungsi pengawasan dapat berjalan efektif dan efisien. Pemeriksaan dilakukan dengan menyusun rencana pemeriksaan dalam satu tahun. Sepanjang tahun ada jadwal pemeriksaan yang dilakukan baik dalam tahap perencanaan, pelaksanaan maupun pasca kegiatan. 


\section{PEMBAHASAN}

Pengawasan internal pemerintah kabupaten secara keseluruhan merupakan tanggung jawab Bupati. Cakupan pengawasan yang menjadi kewenangan kabupaten diatur di dalam Peraturan Daerah tentang Kewenangan Kabupaten yang ditindaklanjuti dengan Peraturan Bupati Pekalongan No 56 tahun 2013 tentang Kebijakan Pengawasan Atas Penyelenggaraan Pemerintahan Daerah di Lingkungan Pemerintah Kabupaten Pekalongan. Sesuai dengan kewenangan yang dimiliki auditor tidak hanya sekedar menjadi konsultan tetapi harus mampu berperan sebagai katalisator atau quality assurer, artinya pengawasan harus mampu memastikan bahwa usul-usul perbaikan yang diajukan dapat (LAN, 2003).

Dokumen perencanaan yang disusun belum digunakan dengan baik untuk menjadi pedoman dalam penyusunan anggaran, sehingga masih ditemukan kegiatan yang diusulkan tidak ada dalam renstra atau sebaliknya. Renstra seharusnya menjadi dokumen pedoman utama dalam penyusunan anggaran sehingga semua kegiatan yang dianggarkan dapat dideteksi dalam dokumen renstra.

Secara kuantitas dan kualitas aparat pengawas masih sangat kurang, sehingga audit yang dilakukan tidak dapat menyeluruh. Disamping itu mutasi pegawai inspektorat (yang sudah mendapatkan pelatihan teknis pengawasan) ke SKPD lain sebagai akibat kebijakan kepegawaian daerah dan minimnya anggaran yang hanya 0,1 persen dari kebutuhan ideal menjadi penyebab terbatasnya obyek yang harus diaudit. Kondisi tersebut menunjukkan komitmen pemerintah kabupaten Pekalongan yang belum maksimal dalam memberikan perhatian baik dari sumberdaya personil, keuangan dan sarana.

Penerapan SPIP belum optimal, satgas SPIP belum mempunyai kemampuan yang handal dalam melakukan pengawasan dalam unit satuan kerjanya. Disamping itu ketidakpatuhan terhadap peraturan perundangundangan masih rendah, dan belum terdapat Standard Operating Procedures 
(SOP) yang baku dalam pelaksanaan pengawasan. Berdasarkan pendekatan manajemen deskriptif, fungsi pengawasan terhadap penggunaan sumberdaya publik menjadi hal yang sangat strategis. Apabila penyelenggaraan pemerintahan harus berjalan efektif dan efisien, maka pengawasan harus mendapatkan perhatian yang cukup dari sisi sumberdaya.

Untuk memperkuat pengawasan Bupati Kabupaten Pekalongan telah menerbitkan Keputusan Bupati Pekalongan No 060/225 tahun 2014 tentang Pembentukan Tim Penyusun Road Map Reformasi Birokrasi di Lingkungan Pemerintah Kabupaten Pekalongan. Terbitnya keputusan bupati tersebut menunjukkan adanya semangat dalam penyelenggaraan pemerintahan yang efektif dan efisien, termasuk di dalamnya adalah penguatan pengawasan.

Penyelenggaraan SPIP di lingkungan mulai diterapkan (peraturan Bupati Pekalongan No 55 tahun 2013) walaupun dalam pelaksanaannya belum optimal. Dalam SK Bupati tersebut setiap SKPD diwajibkan membentuk satgas SPIP, yang diharapkan dapat melakukan perbaikan pada area-area yang masih dianggap lemah. Peningkatan kualitas aparatur SPIP melalui pengiriman diklat SPIP ke BPKP (melalui alokasi anggaran masing-masing SKPD) menjadi faktor prioritas yang harus dilaksanakan.

Peningkatan sarana bekerja berupa sepeda motor sebanyak 11 motor, sehingga dapat menjangkau lokasi audit yang di daerah yang belum baik kondisi jalannya. Walaupun dengan jumlah personil yang sangat terbatas (jabatan fungsional auditor 6 orang dan jabatan fungsional P2UPD 11 orang), pemeriksaan reguler dapat mencapai 144 SKPD, pemeriksaan kasus 20 dan pemeriksaan khusus sekitar 15 dalam setiap tahun.

Untuk menjaga integritas aparatur telah dilakukan penandatangan pakta integritas antara pimpinan SKPD dengan BPK maupun BPKP. Penandatanganan pakta integritas ini diharapkan mampu menjadi penuntun aparatur dalam menjalankan tugas sesuai dengan tupoksi dan sumpah jabatan. 


\section{PENUTUP}

\section{Simpulan}

Sesuai dengan Peraturan Bupati Pekalongan No 56 tahun 2013 tentang Kebijakan Pengawasan Atas Penyelenggaraan Pemerintahan Daerah di Lingkungan Pemerintah Kabupaten Pekalongan, aparat pengawas intern pemerintah (APIP) pada inspektorat kabupaten melakukan :

a. Pengawasan terhadap pelaksanaan urusan pemerintahan di daerah kabupaten

b. Pengawasan terhadap pembinaan atas penyelenggaraan pemerintahan desa

c. Pengawasan terhadap pelaksanaan urusan pemerintahan desa

d. Pengawasan intern atas penyelenggaraan tugas dan fungsi perangkat daerah termasuk akuntabilitas keuangan daerah, dalam rangka memperkuat dan menunjang efektivitas SPIP.

Dalam peraturan bupati tersebut ruang lingkup pengawasan meliputi :

a. Pengawasan terhadap penyelenggaraan pemerintahan daerah, yang meliputi:

- Administrasi umum pemerintahan, yang meliputi : Kebijakan; Kelembagaan; Pegawai; Keuangan; dan Barang Daerah

- Urusan pemerintahan

b. Pengawasan terhadap pelaksanaan pembinaan penyelenggaraan urusan pemerintahan desa

c. Pengawasan terhadap penyelenggaraan administrasi pemerintahan desa

d. Pengawasan terhadap penyelenggaraan SPIP di lingkungan pemerintah kabupaten

e. Penanganan pengaduan masyarakat sehubungan dengan kinerja inspektorat maupun pengaduan lain yang mengandung unsur pengawasan

f. Pengawasan dengan yang difokuskan pada materi atau obyek khusus (tujuan tertentu). 
Jumlah auditor yang terbatas menyebabkan pekerjaan pemeriksaan yang dilakukan juga terbatas. Dalam satu tahun anggaran pemeriksaan reguler mencapai 144 SKPD, pemeriksaan kasus 20 an dan pemeriksaan khusus sekitar 15 dalam setiap tahun. Pimpinan SKPD sudah menandatangani pakta integritas baik dengan BPK dan BPKP, sehingga diharapkan fungsi pengawasan dapat berjalan efektif dan efisien. Pemeriksaan dilakukan dengan menyusun rencana pemeriksaan dalam satu tahun. Sepanjang tahun ada jadwal pemeriksaan yang dilakukan baik dalam tahap perencanaan, pelaksanaan maupun pasca kegiatan.

Adapun masalah-masalah dalam pengawasan adalah sebagai berikut:

a. Dokumen renstra belum menjadi sumber rujukan dalam menyusun kegiatan-kegiatan yang dilakukan. Masih ditemui beberapa kegiatan yang dianggarkan tetapi tidak dapat dijumpai dalam dokumen renstra.

b. Secara kuantitas dan kualitas aparat pengawas (auditor) masih sangat kurang, sehingga audit yang dilakukan bersifat terbatas.

c. Kebijakan dalam bidang kepegawaian kurang mendukung sehingga auditor yang telah berpengalaman harus mutasi ke SKPD lain, hal ini menjadi salah satu penyebab berkurangnya auditor.

d. Minimnya anggaran yang hanya 0,1 persen dari kebutuhan ideal menjadi penyebab terbatasnya obyek yang harus diaudit.

e. Penerapan SPIP belum optimal, karena masih terbatasnya kemampuan satgas SPIP dalam tiap-tiap SKPD.

f. Belum terdapat Standard Operating Procedures (SOP) yang baku dalam pelaksanaan pengawasan

g. Belum terakomodirnya program (dalam RPJMD) penataan dan penyempurnaan prosedur pengawasan dalam anggaran.

\section{Rekomendasi}

a. Perlu komitmen yang kuat dan keteladanan pimpinan dalam penyelenggaraan pemerintahan yang bersih, bebas dari korupsi kolusi dan nepotisme, sehingga peningkatan opini BPK dari WDP (Wajar Dengan 
Persyaratan) menjadi WTP (Wajar Tanpa Persyaratan) dapat dicapai.

b. Perlu penambahan personil secara bertahap dalam lima tahun menjadi 35 orang JF PPUPD (Pejabat Pengawas Urusan Pemerintahan Daerah) dan 40 auditor agar jumlah ideal inspektorat dapat terpenuhi dan dapat menjalankan tugasnya dengan optimal.

c. Perlu penambahan dana operasional yang memadai, karena selama ini Inspektorat hanya menerima $1,5 \mathrm{M}(0,1$ persen) dari dana ideal yang seharusnya diterima sebesar 15 M (1 persen dari APBD).

d. Peningkatan kualitas aparatur SPIP melalui pengiriman diklat SPIP ke BPKP (melalui alokasi anggaran masing-masing SKPD). Peningkatan kualitas aparatur SPIP disetiap SKPD sehingga dapat membantu inspektorat dan mencegah terjadinya tindak maladministrasi dan fraud (penyimpangan) dalam penyelenggaraan pemerintahan.

\section{DAFTAR PUSTAKA}

Bungin, Burhan, 2003, Analisis Data Penelitian Kualitatif, Pemahaman Filosofis dan Metodologis Ke Arah Penguasaan Model Aplikasi, PT Raja Grafindo Persada, Jakarta

Dunn, William.N, 2003, diterjemahkan oleh Samodra Wibawa dkk, Pengantar Analisis Kebijakan, Gadjah Mada University Press, Yogyakarta

Keban, Yerimias T, Enam Dimensi Strategis Administrasi Publik, 2008, Gava Media, Yogyakarta

LAN, Sankri, Buku 1 Prinsip-prinsip Penyelenggraan Negara, 2003, Perum Percetakan Negara RI, Jakarta

Mardikanto, Totok; Soebiato, Poerwoko, 2012, Pemberdayaan Masyarakat, Dalam Perspektif Kebijakan Publik, Alfabeta, Bandung

Miles Mattew B; Huberman Michael A, 1984, Qualitative Data Analysis; A Sourcebook of New Methods, Sage Publications, Beverly Hills, London

Nugroho, Iwan dan Rochim Dahuri, 2004, Pembangunan Wilayah, Perspektif Ekonomi, Sosial dan Lingkungan, LP3ES, Jakarta 
Subarsono AG; 2011, Analisis Kebijakan Publik Konsep, Teori dan Aplikasi, Pustaka Pelajar, Yogyakarta

Sugiyono, 2005, Memahami Penelitian Kualitatif, CV. Alfa Beta, Bandung

Tjokrowinoto, Moeljarto, 1996, Pembangunan Dilema dan Tantangan, Pustaka Pelajar, Yogyakarta

Peraturan Pemerintah No 60 tahun 2008 tentang Sistem Pengendalian Intern Pemerintah

Peraturan Presiden No 5 Tahun 2010 tentang Rencana Pembangunan Jangka Menengah Nasional (RPJMN) tahun 2010-2014;

Permenpan-RB No 20 tahun 2010 tentang Road Map Reformasi Birokrasi 2010 2014

Peraturan Presiden No 81 tahun 2010 tentang Grand Design Reformasi Birokrasi $2010-2025$

Permendagri No 23 tahun 2007 tentang Pedoman Tatacara Pengawasan atas Penyelenggaraan Pemerintahan Daerah

DDA Kabupaten Pekalongan Dalam Angka 2012, BAPPEDA Kabupaten Pekalongan dan BPS Kabupaten Pekalongan

Perda Kabupaten Pekalongan No 6 tahun 2011 tentang Organisasi dan Tatakerja Lembaga Teknis Daerah, Satuan Polisi Pamong Praja dan Badan Penanggulangan Bencana Daerah

Perda Kabupaten Pekalongan No 8 tahun 2011 tentang RPJMD Kabupaten Pekalongan tahun 2011-2016

Peraturan Bupati Pekalongan No 55 tahun 2013 tentang Penyelenggaraan Sistem Pengendalian Intern Pemerintah di Lingkungan Pemerintah Kabupaten Pekalongan

Peraturan Bupati Pekalongan No 56 tahun 2013 tentang Kebijakan Pengawasan atas Penyelenggaraan Pemerintahan Daerah di Lingkungan Pemerintah Kabupaten Pekalongan

Keputusan Bupati Pekalongan No 60/225 tahun 2014 tentang Pembentukan Tim Penyusun Road Map Reformasi Birokrasi di Lingkungan Pemerintah Kabupaten Pekalongan 
BPK RI Perwakilan Provinsi Jawa Tengah, Hasil Pemeriksaan atas Laporan Keuangan Pemerintah Kabupaten Pekalongan tahun 2013 